\title{
Occurrence of Babesia bigemina and Anaplasma marginale in clinically affected cattle in western Santa Catarina, Brazil
}

Ocorrência de Babesia bigemina e Anaplasma marginale em bovinos clinicamente acometidos na região oeste de Santa Catarina, Brasil

VANAZZI ${ }^{1}$, Daniela Lourdes

https://orcid.org/0000-0001-5497-2655

RIGO$^{1}$, Tanaíza Carla

https://orcid.org/0000-0002-2703-9461

BALDASSO ${ }^{1}$, Núbia Deconto

https://orcid.org/0000-0001-9053-3035

COLLET $^{1}$, Silvana Giacomini

https://orcid.org/0000-0002-1391-9468
PRESTES ${ }^{1}$, Alan Miranda

https://orcid.org/0000-0001-8794-0166

BIONDO $^{1}$, Natalha

https://orcid.org/0000-0002-0367-4882

SAVARIS ${ }^{1}$, Thaiza

https://orcid.org/0000-0002-0413-8563

CAMILLO $^{1 *}$, Giovana

https://orcid.org/0000-0003-0971-706X

\footnotetext{
${ }^{1}$ Universidade do Oeste de Santa Catarina - Departamento de Medicina Veterinária - Xanxerê, SC, Brazil.

*Corresponding author: giovana.camillo@unoesc.edu.br
}

\begin{abstract}
The objective of this study was to obtain data on the occurrence of Babesia bigemina e Anaplasma marginale in cattle with characteristic clinical signs of the disease, in different properties in western Santa Catarina. For this, 149 blood sample were collected and slides smears were done and the staining with the Romanowsky kind dye subsequently. Of the 149 samples surveyed, $78(52.35 \%)$ were positive for $A$. marginale, 04 (2.68\%) for $B$. bigemina, and $03(2.01 \%)$ samples showed co-infection. All described cases occurred in adult animals, from two years old, with Holstein females the highest occurrence represented 119/149 (79.86\%). Regarding the presence of ectoparasites, hematophagous flies were observed in all properties and ticks in 58/149 (38.92\%) animals. The results showed a higher occurrence of $A$. marginale, evidencing the need to seek strategies of control and prevention by the veterinary professionals, especially in moments of greater occurrence of the vectors. The confirmation as from laboratory support by stained blood smears beyond being cheaper practical is a method that helping professionals identify the suspected cases etiology. Moreover, based on this information, we can promote the elaboration of prevention and treatment strategies based on simple and fast diagnostic techniques, focused on especific disease agents.
\end{abstract}

Keywords: Diagnosis, Hemoparasites, Anaplasmosis, Ectoparasites 


\section{RESUMO}

O objetivo desse estudo foi obter dados de ocorrência $B$. bigemina. e A. marginale em bovinos com sinais clínicos característicos da doença em diferentes propriedades da região oeste de Santa Catarina. Para isso, foram coletadas 149 amostras de sangue, para posterior confecção de esfregaço em lâminas e a realização da coloração com o corante tipo Romanowsky. Das 149 amostras pesquisadas, 78 (52,35\%) foram positivas para $A$. marginale, $04(2,68 \%)$ para $B$. bigemina e 03 (2,01\%) amostras apresentaram coinfecção. Todos os casos descritos ocorreram em animais adultos, a partir de dois anos de idade, com maior ocorrência em fêmeas da raça holandesa 119/149 (79,86\%). Quanto à presença de ectoparasitas, foram observadas moscas hematófagas em todas as propriedades e carrapatos em 58/149 (38,92\%) animais. Os resultados demonstram uma maior ocorrência de $A$. marginale evidenciando a necessidade dos profissionais buscarem estratégias de controle e prevenção, principalmente nas épocas de maior ocorrência dos vetores. A confirmação a partir do suporte laboratorial, por esfregaço de sangue corado, além de prático e barato, é um método que ajuda os profissionais a identificar a etiologia dos casos suspeitos. Além disso, com base nessas informações, podemos promover a elaboração de estratégias de prevenção e tratamento com base em técnicas simples e rápidas de diagnóstico, focadas em agentes específicos da doença.

Palavras-chave: Diagnóstico, Hemoparasitas, Anaplasmose, Ectoparasitas

\section{INTRODUCTION}

Bovine Babesiosis and Anaplasmosis are an important infectious and parasitic complex for cattle, especially in southern Brazil, an important milk producer region. These diseases are high morbidity and mortality and generally presents a significant decrease in the production of meat and milk, besides high costs with treatment and animal losses (GONÇALVES, 2000; BARROS et al., 2005; TRINDADE et al., 2011). Babesiosis is caused by the protozoans B. bigemina and Babesia bovis and Anaplasmosis is caused by rickettsia $A$. marginale, these associated agents cause the Bovine Babesiosis and Anaplasmosis complex (ALMEIDA et al., 2006; GUEDES JÚNIOR et al., 2008; AMORIM et al., 2014). The major hemoparasites transmitter for cattle is the Rhipicephalus (Boophilus) microplus tick. In addition, hematophagous flies like Stomoxys calcitrans, Haematobia irritans and Tabanus spp.), feeders and blood transfusion can also act on the transmission of $A$. marginale (SOUZA et al., 2000; RADOSTITS et al., 2002; AUBRY AND GEALE, 2011). Among the clinical signs observed in this disease, hyperthermia, anemia, prostration, tachycardia, tachypnea, icterus and hemoglobinuria are common. Neurological signs are restricted to $B$. bovis infected cattle (RADOSTITS et al., 2002).

For clinical diagnosis of tick borne disease, epidemiological data and clinical signs must be taken into account, however, it is not definitive. The laboratory support is an important tool to confirm the etiology of clinical condition (RADOSTITS et al., 2002; TRINDADE et al., 2011). The necropsy examination helps the diagnosis of animals that die because of the tick borne disease; however, the confirmation is through histopathology exam. For the agents identification, the diagnostic methods 
include Giemsa staining, or Romanowsky dye, in blood smears or tests such as agglutination, complement fixation, ELISA, "Western blot", polymerase chain reaction (PCR) and a modified technique known as multiplex PCR (mPCR) (VIDOTTO \& MARANA, 2001; ZHOU et al., 2016; VIEIRA et al., 2019). Among the possible diagnosis techniques, the agent observation in blood smears stained with Romanowsky dye is a practical, effective and low-cost method besides being possible to be used by extensionist professionals (TRINDADE et al., 2011).

The study aimed to establish which hemoparasite has a higher occurrence in clinically affected cattle in the west region of Santa Catarina, which concentrates large production of milk and meat, composing thousands of families income, highlighting the importance of this disease in cattle.

\section{MATERIAL AND METHODS}

From June 2017 to February 2018, 149 blood samples from dairy cattle showing clinical signs of babesiosis and anaplasmosis were investigated in the western region of Santa Catarina state. For this, clinical veterinarians from the region helped with the collection. All sampled animals were chosen at random, considering all those that showed clinical signs compatible with hyperthermia, apathy, anemia, icterus and decreased milk production, on each property. These animals were from small, medium and large properties, with semi-intensive and intensive breeding systems, located. This study was approved by CEUA, by the number 29/2017.

To obtain the epidemiological data, at the time of sampling, a form was filled out. The objective was to collect information about the animal, including age, breed, sex and also to observe animals that presented ectoparasites such as flies and ticks. In addition, data were recorded on properties that had veterinary assistance.

Blood samples from clinically affected animals were collected with the aid of a disposable vacutainer-type needle directly from the coccygeal vein in 10 $\mathrm{mL}$ vials containing EDTA as anticoagulant. Samples were identified, stored and refrigerated until processing. Posteriorly, blood smears slides were prepared and stained with Romanowsky dye (Panótico rápido - Laborclin ${ }^{\circledR}$ ), according to the manufacturer's recommendations. The agents species were characterized through the morphology analysis in the slides evaluation in optical microscope, Opticam ${ }^{\circledR}$ (T3.15A), 1000x ocular, with immersion oil. The diagnosis was based on observation and interpretation of the smear according to Hendrix (2006) and Stockaham et al. (2011).

Data analysis was performed using the statistical software SAS (SAS, 2015) and the variables compared using the Chisquare test $\left(\mathrm{x}^{2}\right)$ with a significance level of $5 \%(\mathrm{p}=0.05)$ using the FREQ procedure.

\section{RESULTS}

Among the 149 analysed samples in 64 properties, $78(52.35 \%)$ were positive for $A$. marginale, 04 positive for $B$. bigemina (2.68\%) and in 03 samples $(2.01 \%)$ it was possible to identify both hemoparasites ( $B$. bigemina and $A$. marginale) in the same animal (Table 1). All the evaluated cases included adult animals, ranging from two to five years old. Considering that were both milk producing and meat production 
properties, the main breeds diagnosed with bovine babesiosis and anaplasmosis in this study were Holstein cattle with $119(79.86 \%)$, followed by Jersey 12 $(8.05 \%)$, Hereford $12(8.05 \%)$ and Nelore 06 (4.03\%). Regarding the gender, there was a higher ocurrence of positivity in females, 132 (88.59\%) cases.

In all researched properties there were the presence of hematophagous flies (Haematobia irritans) as bovine anaplasmosis agents transmitting vectors, being more frequent compared to ticks presence. Ticks were observed in $39.59 \%(59 / 149)$ of the sampled animals.
Of the 74 animals positive for $A$. marginale, in $55.4 \%(41 / 74)$ it was possible to correlate with the occurrence of tick on the property. In the four animals parasitized by $B$. bigemina, ticks were not observed at the time of collection, since the pro had recently carried out chemical control. The highest occurrence of fly and tick infestation was observed in the period from October to January.

The clinical signs most frequently described in animals were apathy, hyperthermia, anemia, decreased milk production, tachycardia, and tachypnea.

Table 1 - Occurrence of etiological agents of bovine Babesiosis and Anaplasmosis complex in animals presenting the disease compatible clinical signs in the Western region of Santa Catarina, Brazil.

\begin{tabular}{ccc}
\hline Agent & Occurrence & $\%$ \\
\hline A. marginale & 78 & 52.35 \\
\hline B. bigemina & 4 & 2.68 \\
\hline A. marginale and B. bigemina & 3 & 2.01 \\
\hline Negatives & 64 & 42.95 \\
\hline Total & $\mathbf{1 4 9}$ & $\mathbf{1 0 0 \%}$
\end{tabular}

\section{DISCUSSION}

The bovine Babesiosis and Anaplasmosis complex causes direct impact on the health and welfare of cattle, in addition to economic losses, which translates into high costs of treatment, prophylaxis, besides affects composition or quality of milk (PAZINATO et al, 2016) The laboratory diagnosis by blood smear is a very practical method that assists the evaluation of hemoparasites occurrence and consequently the control and prevention of the disease. The laboratory results of this study demonstrated a higher occurrence of the A. marginale $(52.35 \%)$ in the blood smear samples. It can be explained by the fact that this agent is easily transmitted either by the tick $R$. microplus or hematophagous insects, as well as blood transfusions (KESSLER, 2001).

Marana et al. (2009) and Carvalho (2010) also describe $A$. marginale as the most prevalent agent, although using a different diagnostic technique. The large number of vectors, as well as the favorable climate for its multiplication may have contributed to a higher 
occurrence of rickettsia, according to what was reported by Trindade et al. (2001). Marana et al. (2009), that characterized the Paraná state as an $A$. marginale enzootic instability region after detecting a prevalence of $58.74 \%$. The western region of Santa Catarina comprises a possible enzootic instability area, since animals pass by periods without any contact with vectors, which is propiciated by the climatic variation.

The investigation of genus Babesia spp., revealed a percentage of $2.68 \%$ positive samples for $B$. bigemina. Paula et al. (2015), in a similar study, using the same technique, identified a higher percentage, being $52.5 \% \quad(21 / 40)$ positive samples for the genus Babesia spp. This difference can be related to the location of the blood collection, which was through the puncture of the dorsal coccygeal vein that reduced the chances of finding B. bovis. This species has viscerotropic characteristics and can be better observed in imprint smears from brain tissue, and may present parasitemia as high as $90 \%$ of the infected erythrocytes. Unlike infected erythrocytes in peripheral blood where this species is usually found in parasitemia below 1\% (ALVAREZ et al., 2019).

Another cause of the low occurrence of Babesia spp. and the negative samples percentage in this study may be related to the parasitemia level and sensitivity of performed test. In heavy infestations, confirmatory diagnosis can also be done through microscopy analyzing Giemsa stain blood smears (JAIMES DUENEZ et al., 2017). However, in low parasitemia cases, only molecular diagnostic techniques allow the detection of Babesia spp. (CREATEDFORNELIO, 2007). In addition, the reality found in the study area and reported by Paula et al. (2015) may be related to the antimicrobials and babesicides administration. Often, the veterinarian is called for assistance only in cases of emergency, and the animals are treated by the owners, empirically, based only on clinical signs. According to Souza et al. (2013), when the treatment is instituted in the initial phase of the disease, the animals can recover and this fact can contribute to the increase in the number of negative samples in the act of collection, interfering in the results, generating false negatives.

In Santa Catarina state, Souza et al. (2002) determined the prevalence of specific antibodies against Babesia spp. and identified a higher percentage for the species $B$. bigemina, varying between age groups, with $74.02 \%$ to $95.12 \%$. However, it must be taken into account that the techniques used have different purposes, while Souza et al. (2002) verified the presence of antibodies, which does not require high parasitemia, this study sought to identify active infection in animals. In southern Rio Grande do Sul, Almeida et al. (2006), in a retrospective study, identified $B$. bovis more frequently (41\% of cases) and, according to the author, this total may be even greater due to the fact that in some places where Babesiosis outbreaks occurred, the agents have not been identified.

Infections by both agents, which characterizes tick borne disease complex, were low, being detected in only three cases $(2.01 \%)$. Similarly, low prevalence of coinfection was also identified by Paula et al. (2015) and Almeida et al. (2006) with $04(10 \%)$ and $21(9.5 \%)$ cases, respectively. Although the low occurrence found in the clinically affected animals, the 
possibility of this type of coinfection should not be ruled out.

The occurrence of clinically affected animals and parasitized in this study was $57.04 \%$, and the highest occurrence of hemoparasites occurred in the period from October to January. In the western region of Santa Catarina, at this time of year the temperatures are higher and consequently climatic conditions favor the vectors development. It is important to consider that the southern region of Brazil is characterized as enzootic instability area, since animals remain free of contact with the disease agents in a certain period of the year due to low temperatures (MARANA et al., 2009). Souza et al. (2002) performed a serological survey for Babesia sp. in the northern plateau of Santa Catarina and also defined it as enzootic instability region for this agent. The results of this research disagree with the results reported by Casa (2017) in Lages, Santa Catarina, which defined this area as of enzootic stability for $A$. marginale. According to the author, at the time of samples collection the animals were asymptomatic, since the vectors circulated in the region, maintaining the immunity for $A$. marginale and the animals free from the clinical disease.

According to Casa (2017), the low number of ticks on the animals is a predisposing factor to the low occurrence of Babesiosis, found in this study. It is worth mentioning that the low infestation of ticks in the sampled animals during the study period is due to the fact that were frequently controlled by the owners, by using chemical carrapaticides. The concern of producers to control ticks excessively, assuming inadequate management practices is often related to outbreaks of Babesiosis and Anaplasmosis. This is due to the reduction in inoculation rate of Babesia spp. and consequent decreased immunity of the animals (D'ANDREA et al., 2006). The higher occurrence of $A$. marginale may be related to the presence of flies and ticks, since there was a correlation of $55.4 \%$ of animals infected with this rickettsia that presented ticks simultaneously. In conversation with the producers, it was possible to perceive greater concern with the prophylaxis of ticks and a certain neglect in relation to the prophylaxis of hematophagous flies. This fact can contribute a lot to the spread and persistence of $A$. marginale in cattle herds.

When the influence of the breeds was investigated, there was no significant difference. The Holstein breed has predominance in region, which generated a large number of positive samples for the disease agents in this breed. Marana et al. (2009), investigated the seroprevalence of $A$. marginale in cattle in South-Central region of Paraná, and also verified that breed did not influence the results. Regarding the gender, there was a higher positivity in females with $132(88.59 \%)$ cases, due to most of the properties sampled belong to the dairy activity, which is in accordance with that verified by Casa (2017), where the majority of Anaplasma positivity were in females. This result differs from that found by Trindade et al. (2011), which found no difference in relation to gender.

Based on data, it can be stated that most of the sampled properties do not have veterinary assistance. This situation was also observed in the study by Paula et al. (2015) in which animals are treated by producers with drugs according to clinical signs. Therefore, it is likely the use of medication by the producers may have influenced the negative samples 
result to the agents. In practice, it is very common to observe veterinarian establishes the field treatment based only on the clinical signs observed in the animal, without aid of laboratory diagnosis and without considering which agent is involved specifically. This was reported by Souza (2011), who verified the occurrence of deaths suggestive of the disease, but without definitive diagnosis. Most established treatment protocols include the use of antimicrobials, oxytetracyclines and/or enrofloxacin, associated with babesicides as diaminezene aceturate. Almeida et al. (2006) commented that in the occurrence of outbreaks with mortality, only the animals' blood was collected and sent for diagnosis, since clinical signs are easily identified by professionals and laypeople working in the field.

The use of complementary diagnostic tools is not always possible due to the need to institute an immediate treatment for animals. However, the blood smear and agent observation through microscopic is a fast, practical and inexpensive alternative that veterinarians can use. Although this method is useful only for the detection of infected erythrocytes during the acute phase of the disease and with the high number of parasites present in circulating blood (ALVAREZ et al., 2019), this tool allows the clinician to institute specific treatment for the causative agent of disease, avoiding excessive spending, and excluding other differential diagnoses.

\section{CONCLUSION}

Thus, the laboratory results showed a higher occurrence of the A.marginale in clinically affected cattle in the west region of Santa Catarina. In addition, the higher occurrence of $A$. marginale may be related to the presence of flies and ticks.

\section{ACKNOWLEDGMENT}

To the scholarship program of Santa Catarina (UNIEDU) - University of West Santa Catarina.

\section{CONFLICT OF INTEREST}

The authors declare no conflict of interest and disclose no financial relationship with people or organizations that could bias this work.

\section{REFERENCES}

ALVAREZ, J.A.; ROJAS, C.; FIGUEROA, J.V. Diagnostic Tools for the Identification of Babesia sp. in Persistently Infected Cattle. Pathogens, v.8, p. 143, 2019.

ALMEIDA, M.B.; TORTELLI, F.P.; CORREA, B.R.; FERREIRA, J.L.M.; SOARES, M.P.; FARIAS, N.A.R.; CORREA, F.R.; SCHILD, A.L. Tristeza parasitária bovina na região sul do Rio Grande do Sul: estudo retrospectivo de 1978-2005. Pesquisa Veterinária Brasileira, v. 24, n. 4, p. 237-242, 2006.

AMORIM, L. S.; WENCESLAU, A. A.; CARVALHO, F. S.; CARNEIRO, P. L. S.; ALBUQUERQUE, G. R. Bovine babesiosis and anaplasmosis complex: diagnosis and evaluation of the risk factors from Bahia, Brazil.

Brazilian Journal of Veterinary

Parasitology, v. 23, n. 3, p. 328-336, 2014. 
AUBRY, P., GEALE, D.W. A review of bovine anaplasmosis. Transbound Emergence Disease. v.58, p.1-30, 2011.

BARROS, S.L.; MADRUGA, C.R.; ARAUJO, F.R.; MENK, C.F.; ALMEIDA, M.A.O.; MELO, E.P.S.; KESSLER, R.H. Serological survey of Babesia bovis, Babesia bigemina, and Anaplasma marginale antibodies in cattle from the semi-arid region of the state of Bahia, Brazil, by enzyme-linked immunosorbent assays. Memórias do Instituto Oswaldo Cruz, v. 100, p. 613-617, 2005.

CARVALHO, André Henrique Oliveira de. Estudo epidemiológico de Anaplasma marginale e Babesia bovis em bezerras de propriedades produtoras de leite tipo B e cru refrigerado na região do Campo das Vertentes de Minas Gerais. 2010. Dissertação (Pós-Graduação em Ciências Veterinárias) - Universidade Federal de Lavras, Minas Gerais.

CASA, Mariana da Silva. Prevalência e fatores associados à infecção por Anaplasma Marginale, Babesia bovis e Babesia bigemina em bovinos da raça Crioula lageana. 2017. 132p. Tese (Mestrado em Ciência Animal) Universidade do Estado de Santa Catarina.

CRIADO-FORNELIO, A. A review of nucleic acid-based diagnostic tests for Babesia and Theileria, with emphasis on bovine piroplasms. Parassitologia, V.49, P.39-44, 2007.

D'ANDREA, L.A.Z.; SARTOR, I.F.; MADRUGA, C.R.; FREITAS, S.B.Z.; KROLL, L.B.; KRONKA, S.N.
Condição imunológica de bovinos das raças Holandesa e Nelore frente a $B$. bovis e $B$. bigemina em duas regiões do Estado de São Paulo. Pesquisa

Veterinária Brasileira, v. 26, n. 2, p. 74-78, 2006.

GONÇALVES, P.M. Epidemiologia e controle da Tristeza Parasitária Bovina na região sudeste do Brasil. Revista Ciência Rural, v. 30, n. 1, p. 187-194, 2000.

GUEDES JUNIOR, D.S.; ARAUJO, F.R.; SILVA, F.J.M.; RANGEL, C.P.; NETO, J.D.B.; FONSECA, A.H. Frequency of antibodies to Babesia bigemina, B. bovis, Anaplasma marginale, Trypanosoma vivax and Borrelia burgdorferi in cattle from the Northeastern region of the State of Pará. Brazil. Revista Brasileira de Parasitologia Veterinária, v. 17, n. 2, p. 105-109, 2008.

HENDRIX C.M. Exame Citológico: In: Cowell R.L. \& Dorsey K.E. (Eds), Procedimentos Laboratoriais para técnicos veterinários, Editora Roca, 2006. 472-486 p.

JAIMES-DUENEZ, J.; TRIANACHAVEZ, O.; MEJÍAJARAMILLO, A. M. Parasitological and molecular surveys reveal high rates of infection with vector-borne pathogens and clinical anemia signs associated with infection in cattle from two important livestock areas in Colombia Ticks.

Tick-borne Disease, v.8, p. 290-299, 2017.

KESSLER, R.H. Considerações sobre a transmissão de Anaplasma marginale. Pesquisa Veterinária Brasileira, 21(4):177-179, 2001. 
MARANA, E.R.M.; DIAS, J.A.; FREIRE, R.L.; VICENTINI, J.C.; VIDOTTO, M.C.; VIDOTTO, O. Soroprevalência de Anaplasma marginale em bovinos da região Centro-Sul do estado do Paraná, Brasil, por um teste imunoenzimático competitivo utilizando proteína recombinante MSP5-PR1. Revista Brasileira de Parasitologia Veterinária, Jaboticabal, v. 18, n. 1, p. 20-26, 2009.

PAULA, M.A.M.; OLIVEIRA, F.C.R.; MELO, O.A.; TEIXEIRA, E.F.

Prevalência de Babesia spp. e Anaplasma marginale em bovinos no município de Palma, MG. Revista Brasileira de Medicina Veterinária, v. 37, n.4, p. 359-365, 2015.

PAZINATO, R.; MACHADO, GUSTAVO; KLAUCK, VANDERLEI; RADAVELLI, W. M.; BOITO, JHONATAN P.; WEIS, PAULO H.E.; MILETTI, L. C., BALDISSERA, M. D.; STEFANI, L. M., DA SILVA, A. S. Influence of subclinical infection by agents of tick fever in milking dairy cows. Revista MVZ Cordoba, v. 21, n.3, p. 5490-5499, 2016.

RADOSTITS, O.M.; GAY, C.C.; BLOOD, D.C.; HINCHCLIFF, K.W. Clínica veterinária: um tratado de doenças dos bovinos, ovinos, suínos, caprinos e equinos. 9. ed. Rio de Janeiro: Guanabara Koogan, 2002. xxix, $1737 \mathrm{p}$.

SILVA, J.B.; LOPES, C.T.A.; PINHEIRO, C.P.; LIMA, D.H.S.; SILVA, R.S.L.; FONSECA, A.H.; ARAUJO, F.R.; NETO, J.D.B. Prevalência sorológica e molecular de Babesia bovis e Babesia bigemina em búfalos (Bubalus bubalis) na Ilha de Marajó, Pará. Pesquisa Veterinária Brasileira, Pará, v.33, n. 7, p. 847-850, 2013.

SOUZA, J.C.P.; SOARES, C.O.; SCOFIELD, A.; MADRUGA, C.R.; CUNHA, N.C.; MASSARD, C.L.; FONSECA, A. H. Soroprevalência de Babesia bigemina em bovinos na mesorregião Norte Fluminense.

Pesquisa Veterinária Brasileira, v. 20, p. 26-30, 2000.

SOUZA, A.P.; SURKAMP, V.; BELLATO, V.; SARTOR, A.A.; FARIAS, L.M. Prevalência de anticorpos anti-Babesia em bovinos no planalto norte de Santa Catarina. Revista de Ciências Agroveterinárias, v. 1, n. 1, p. 21-23, 2002.

SOUZA, F.A.L.; BRAGA, J.F.V.; PIRES L.V; CARVALHO, C.J.S.; COSTA, E.A.; RIBEIRO, M.F.B.; SANTOS, R.L.; SILVA, S.M.M.S. Babesiosis and anaplasmosis in dairy cattle in Northeastern Brazil. Pesquisa Veterinária Brasileira. v.33, n.9, p.1057-1061, 2013.

STOCKHAM, S.L. Fundamentos de Patologia Clinica: 2 ed. Rio de Janeiro: Editora Guanabara Koogan, 2011. 687 p. TRINDADE, H.I; ALMEIDA, K.S.; FREITAS, F.L.C. Tristeza parasitária bovina -revisão de literatura. Revista Científica Eletrônica de Medicina Veterinária, n.16, 2011.

TRINDADE, H.I.; ALMEIDA, R.S.; SOUSA, M.G.; TEIXEIRA, M.C.A.; MACHADO, R.Z.; BATISTA, M.C.S.; BATISTA, E.K.F. Frequência de Anaplasma Marginale em bovinos da região de Araguaína, estado do 
Tocantins, Brasil. Revista Ciência

Animal, v. 21, n. 2, p. 119-125, 2001.

VIDOTTO, O.; MARANA, E.R.M.

Diagnóstico em anaplasmose bovina.

Revista Ciência Rural, v. 31, n. 4, p.

361-368, 2001.

VIEIRA， L.L.; CANEVER， M.F.; CARDOZO, L.L.; CARDOSO, C.P.; HERKENHOFF, M.E.; NETO, A.T.; VOGEL, C.I.G.; MILETTI, L.C. Prevalence of Anaplasma marginale, Babesia bovis, and Babesia bigemina in cattle in the Campos de Lages region, Santa Catarina state, Brazil, estimated by multiplex-PCR. Parasite Epidemiology and Control. 6:e00114, 2019.

ZHOU, M.; CAO, S.; SEVINC, F.; SEVINC, M.; CEYLAN, O.; MOUMOUNI, P.F.; JIRAPATTHARASATE, C.; LIU, M.; WANG, G.; IGUCHI, A.; VUDRIKO, P.; SUZUKI, H.; XUAN, X. Molecular detection and genetic identification of Babesia bigemina Theileria annulata Theileria orientalis and Anaplasma marginale in Turkey Ticks. Tick Borne

Disease, v.7, p. 126-134, 2016. 